Erschienen in: The Principal Agent Model and the European Union. / Delreux, Tom; Adriaensen, Johan (Hrsg.). - Cham : Palgrave Macmillan, 2017. - S. 157-180. - ISBN 978-3-319-55136-4 https://dx.doi.org/10.1007/978-3-319-55137-1_7

\title{
Manifest and Latent Control on the Council by the European Council
}

\section{Daniela Annette Kroll}

\section{INTRODUCTION}

From the Eurozone crisis in 2010 to the migration crisis in 2015, the summits of the European Council (EUCO) seem to have become ubiquitous events in the European Union (EU). Yet, while the role of the EUCO on setting the Union's agenda is well established, its impact on day-to-day EU policy-making has received limited scholarly attention. The EUCO is composed of the heads of state or government (HoSG) of the member states and the President of the Commission and, since the Lisbon Treaty entered into force in 2009, chaired by its own President. Although EUCO summits have been regularly held since 1975, the body has only been recognized as an EU institution in the Lisbon Treaty. According to the Treaty, the EUCO "shall define the general political guidelines and priorities" of the EU and "shall not exercise legislative functions" (Article 15(1) TEU). Since the institution has been defined as a non-legislative body, the Council of the $\mathrm{EU}^{\mathrm{l}}$, the European Parliament (EP) and the Commission hold formally the competences for the legislative process. Yet, its lack of legal competences does not prevent the EUCO from taking decisions and, thereby, influencing the EU's legislative process (Wessels 2015: 72ff.). This chapter sheds light on this discrepancy by examining the interactions between the EUCO and the main decision-making body of the EU, the Council (Hayes-Renshaw and Wallace 2006).

Konstanzer Online-Publikations-System (KOPS)

URL: http://nbn-resolving.de/urn:nbn:de:bsz:352-2--t889zrgev99j5

D.A. Kroll ( $\square)$

University of Konstanz, Konstanz, Germany

(C) The Author(s) 2017

T. Delreux and J. Adriaensen (eds.), The Principal Agent Model and

the European Union, Palgrave Studies in European Union Politics,

DOI 10.1007/978-3-319-55137-1_7 


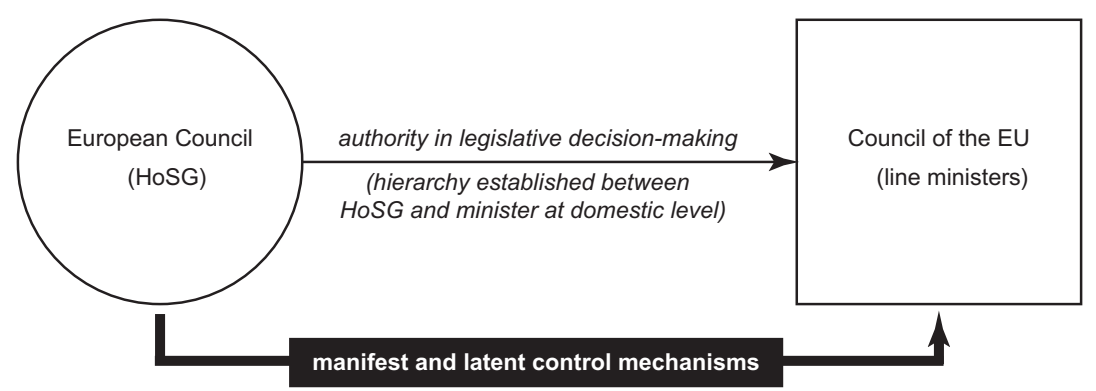

Fig. 1 Visualization of the principal-agent relationship and manifest and latent control

The principal-agent model offers a useful framework to analyze the interactions between the EUCO and the Council. The dyadic relationship examined in this chapter is presented in Fig. 1. Drawing on the hierarchical superior position of the HoSG vis-à-vis their ministers at the domestic level, the EUCO as an institution stands above the Council in the institutional system of the EU. Given that the EUCO is, thus, the collective principal of the Council of the EU, the former is able to influence the legislative activities of the latter. In the principal-agent literature, two control mechanisms between the principal and the agent are distinguished: the principal might control the agent either manifestly or latently. Manifest control of the EUCO on the Council of the EU takes place if the EUCO revises a previous Council position and the decision of the EUCO is taken over by the Council in its subsequent negotiations. Since the EUCO cannot adopt EU laws, its decisions need to be formally adopted by the Council of the EU-and the EP under the ordinary legislative procedure - to have legal effects. The EUCO exercises latent control on the Council if the Council of the EU adopts a legislative act prior to a EUCO summit in anticipation that a decision would be otherwise made by the EUCO. The EUCO is argued to exert control on the decision-making activities of the Council of the EU if a legislative proposal is conflictual within the Council of the EU and if the matter is important for the HoSG.

In this chapter, the two mechanisms of control are empirically illustrated through process-tracing within two pathway cases: firstly, the patent package and secondly, the Council's decisions on the emergency 
relocation system of refugees among the EU member states. The pathway cases have been identified through semi-structured expert interviews. In total, 54 expert interviews have been carried out in Brussels between September 2015 and April 2016. All experts are closely connected to the EUCO and the Council of the EU, with 37 interviewees working as officials in one of the EU institutions, ${ }^{2} 14$ persons being diplomats from the Permanent Representations of the member states and three interviewees being EU journalists. During the interviews that lasted between approximately 30 and 90 minutes, the experts were asked for examples in which the EUCO played a role in the Council's decisionmaking process. Upon the different examples that were mentioned by the interviewees, the two cases have been selected to illustrate the two control mechanisms. Next to the interview data, primary and secondary literature is used. The analysis shows that the EUCO affected the decision-making process in the Council of the EU in both cases, albeit in different ways. In the case of the patent package, the EUCO exercised manifest control on the Council through revising its common position. The second case shows latent control by the EUCO. The expectation that the matter would be transferred to the EUCO if the Council would not decide on the relocation proposal before the summit strengthened cooperation among the winning majority of the member states and, thus, resulted in its formal adoption by QMV. This chapter concludes that the EUCO's position at the apex of the Union's hierarchy enables the institution to influence legislative decision-making through controlling the Council of the EU.

\section{Theoretical Puzzle: The Black Box of Manifest And Latent Control}

Although the EUCO is a key actor of the Union, it plays a secondary role in the literature on EU policy-making. Furthermore, most research on the EUCO is "dated, atheoretical and limited in empirical scope" (Tallberg 2008: 686). In particular, empirical analytical research on the relationship between the EUCO and single EU institutions is lacking. In comparison to the relationship between the EUCO and the supranational institutions (Bocquillon and Dobbels 2013; van de Steeg 2009), scholars have paid less attention to the interaction between the EUCO 
and the Council of the EU. Furthermore, research is characterized by ambiguous and unclear findings. A central point of disagreement concerns the extent to which the two actors interact in EU decision-making. On the one hand, it has been argued that a functional division of labour exists with the EUCO being responsible for constitutive politics, while day-to-day decision-making is made by the Council (Bulmer 1996). On the other hand, some authors find that the EUCO impacts upon the legislative activities of the Council of the EU (Werts 2008: 59; Wessels 2015: 95). However, scholars disagree on the extent to which the EUCO affects the Council's activities. Some argue that the impact of the EUCO is extensive, as the body is unconstrained in its actions. Eggermont (2012), for example, argues that the Council acts under the permanent shadow of the EUCO. Werts (2008: 25) concludes that the EUCO is "largely free to operate as it wishes" (cf. also Hayes-Renshaw and Wallace 2006: 170). Johansson and Tallberg (2010: 209) find that "[i]n effect, all major decisions in the EU nowadays go through the European Council in some shape or form" and that the EUCO is informally able to act on all EU policies. Others argue for a more conditional impact, with the EUCO acting in specific policy areas (Puetter 2014) or issues (Johansson and Tallberg 2010; James and Copeland 2014).

The argument that the EUCO is able to influence the Council's legislative activities implies a principal-agent relationship. In contrast to most other principal-agent relations at the EU level, delegation between the EUCO and the Council lies at the intersection between the domestic and the EU level. Although the EUCO and the Council are both composed of representatives of the EU member states, there is an important hierarchical relationship between the two institutions that is based on domestic power relations. In general, a delegation relationship between the HoSG and the line ministers exists at the domestic level. To qualify as a principal, an actor "must be able to both grant authority and rescind it" (Hawkins et al. 2006: 7), giving the principal "hard control" over the agent (Abbott et al. 2016: 719). Although the formal powers of the HoSG vis-à-vis their ministers vary across the member states (Andeweg 2000; Dunleavy and Rhodes 1990; Helms 2005), the HoSG can usually remove the ministers from office. Since the members of the EUCO possess hard control over the members of the Council of the EU, ministers deviating from the decisions of the EUCO risk losing their domestic office. In contrast to other EU institutions, the EUCO does not derive its authority from its formal powers in the EU treaties, but draws on the 
political clout of its members at the national level. Thus, the hierarchy between the EUCO and the Council is based on the domestic context.

The EU member states have delegated the legislative functions to the Council of the EU, the EP and the Commission through the EU treaties. While the Commission has the power to initiate legislation, the Council-together with the EP under the ordinary legislative procedure-is responsible for the adoption of EU legislation. Given that the EUCO decides on treaty amendments, the HoSG could revoke the Council's authority. Since the EUCO does not possess legislative powers and its decisions fall under soft law (Vogiatzis 2013: 1665), delegation between the Council and the EUCO in the legislative decision-making process is based on a non-formalized, soft contract.

Although the principal-agent model does not make any assumptions about the preferences of principals and agents (Hawkins et al. 2006: 7) and a conflict between the preferences of the principal and the agent is not a necessary condition for its applicability (Wonka 2007: 51; Rasmussen 2005; Delreux and Adriaensen this volume), actors' preferences are a key variable for explaining outcomes in the principal-agent model (Hawkins et al. 2006: 7). Compared to other delegation relations at the EU level, the heterogeneity of preferences between the EUCO and the Council of the EU is less obvious at first sight, since both institutions represent the member states according to the Lisbon Treaty (Article 10(2) TEU). Nevertheless, the preferences of the two institutions might diverge under two conditions. First, the position of the Council of the EU is shaped by sectoral interests that diverge from the interests of the HoSG. While the members of the Council also represent their ministries, the HoSG have to take the interests of different ministries into account and, consequently, they hold broader, cross-sectoral preferences. Negotiating several policy areas simultaneously also allows the EUCO to make issue linkages and package deals that cannot be done by the Council (Scharpf 1999: 130; James and Copeland 2014). Second, the two institutions might hold heterogeneous preferences if the HoSG in the EUCO are from a different party in government than the ministers in the Council. Examining the role of partisanship, Kreppel (2013) finds that policy outcomes in some Council formations could deviate from the median position of all HoSG.

Having mapped the broader context in which the principal-agent relation is embedded, it is desirable to gain more practical insights into the manner in which the EUCO influences Council decision-making. In 
general, principals reduce agents' ability to act autonomously through control. In the principal-agent literature, two mechanisms of how the principal might control the agent are distinguished. Although the agent decides unilaterally on a policy, the agent's choice can be manifestly or latently constrained by the principal (Calvert et al. 1989; Ogul and Rockman 1990). Manifest or "active political" control exists when the principal actively vetoes the decision of the agent, because the policy that the agent would otherwise choose lies outside the agent's zone of discretion (Calvert et al. 1989: 597f.). Latent control occurs when the agent selects a policy other than the agent's ideal point in anticipation of a potential veto by the principal that the agent wants to avoid (ibid.). Latent control brings the agent's decision closer in line with the principal's interests, since the agent would choose a different policy if the agent would not have anticipated the possibility of manifest control by the principal. Hence, the sheer existence of means to exert manifest control can make its actual use unnecessary (Calvert et al. 1989: 599; McCubbins et al. 1987: 249). Epstein and O'Halloran (1995), for example, show that agencies adjust their behaviour strategically to interest groups to avoid them pulling fire alarms to their principal, the Congress. Since the risk of ex post punishment provides the agent enough ex ante incentives to select a policy that lies within its zone of discretion, latent control works prospectively (Ogul and Rockman 1990: 6). By contrast, manifest control occurs post hoc after the agent has selected a policy that lies outside the agent's zone of discretion and that the principal, therefore, reviews (ibid.). While for Calvert et al. (1989: 605) latent control "is in principle just as important as that of active control", Weingast and Moran (1983: 769) argue that control is the more effective, the less a principal needs to control an agent manifestly.

Although the existence of the two control mechanisms is widely acknowledged, the black box of how they work in practice still needs to be opened. Furthermore, principal-agent studies are primarily focused on manifest control given the problem of measuring latent control empirically. Latent control "is, by definition, never observed" (Calvert et al. 1989), leaves few empirical traces (Ogul and Rockman 1990: 21) and confronts scholars with the methodological problem of "observational equivalence" that exists when the observed agency behaviour is consistent with, both, an autonomously acting and latently controlled agent (Weingast and Moran 1983; Pollack 2002: 202). Thus, it is more difficult to test empirically latent control (Ogul and Rockman 1990; 
Reykers and Beach this volume). However, ignoring latent control might lead to an incomplete picture of a principal-agent relation. As stated by Ogul (1976: 10): "[O]versight has been studied primarily as a manifest function-hence the conclusion that little is performed. Awareness of the performance of oversight as a latent function leads to a fuller understanding of the process".

To address the difficulties of measuring latent control, process-tracing is combined with counterfactual reasoning. In line with previous studies, anticipation is measured through the analysis of the temporal sequence of decisions (Leuffen and Hertz 2010, Smeets 2015; Reykers and Beach this volume). To support the evidence, the experts were asked counterfactual questions during the interviews, such as "What do you think would have happened in the Council of the EU if a European Council summit had not been convened?" or "Do you think that the Council of the EU would have adopted the decision if a European Council summit had not taken place?". Though responses to counterfactual questions have to be interpreted cautiously, they are a useful method to uncover the motivations of agents' actions (Rathbun 2008: 693).

According to the principal-agent literature, the level of agency discretion varies across the importance of a policy area for its principals. Since politicians have limited time and resources, they invest them in those policy fields for which "they care the most" to reduce the uncertainty that agents do not pursue their goals, thereby limiting agency discretion (Calvert et al. 1989: 590). Calvert et al. (1989: 589f.) argue that "all else equal, the more important a policy area to politicians, the lower the amount of agency discretion". Being rational actors with the objective of re-election, principals should constrain the choice of their agents stronger on issues that are important to their constituencies. Besides the lower degree of discretion, agents are stronger controlled on issues that are important to principals' constituencies, since fire-alarm oversight in which affected third parties provide information on the agent's behaviour to the principal is concentrated on them (McCubbins and Schwartz 1984). This yields the following hypothesis:

Hypothesis 1: The principal controls the agent if legislative proposals are important for the principal.

In addition to the importance of an issue, principal-agent literature further argues that principals have stronger incentives to monitor and 
to delegate less discretion to agents if conflict within the principal or between the principal and the agent exists. McCubbins and Page (1987), for example, find that conflict within the US Congress leads to more procedural control over an agency. Comparing the presidential US system with parliamentary systems, Epstein and O'Halloran (1999) conclude that legislators limit agency discretion through detailed legislative statutes if conflict existed (cf. also Huber and Shipan 2002). Examining member states' control of the Commission, Blom-Hansen (2013) shows that conflict within and between the legislative EU institutions leads to stricter rules of control by the member states (cf. also Franchino 2000). James and Copeland (2014) find that conflict within the Council might lead to a "reverse delegation" from the Council to the EUCO. If the Council is unable to agree on controversial issues, it might transfer them to the EUCO that is expected to solve the conflict as arbiter of last resort. This type of "delegation failure" (James and Copeland 2014) points to agency loss being caused by the Council's inability to agree on a decision. According to Lupia (2003: 43), an agent may be unable to fulfil the delegated task if the agent lacks the necessary capacities. The simultaneous discussion of issues of several policy fields and its competences over a larger set of policies enables the EUCO to reach decisions by constructing package deals (De Schoutheete and Wallace 2002; Scharpf 1999), issue linkages (James and Copeland 2014: 130) and side payments (Harstad 2008: 469) in contrast to the Council. This yields the following hypothesis:

Hypothesis 2: The principal controls the agent if legislative proposals are conflictual within the agent.

\section{Empirical Analysis: How the European Council Controls the Council}

The control mechanisms of the EUCO on the Council are tested through a case study approach. Since the analysis aims at illustrating the causal mechanisms of how the EUCO controls the Council of the $\mathrm{EU}$, process-tracing within two pathway cases is conducted. Following Gerring (2007), pathway cases are cases in which researchers have previous knowledge that the causal factor of interest XI correctly predicts the outcome $\mathrm{Y}$, but where the causal mechanism linking $\mathrm{XI}$ and $\mathrm{Y}$ remains unspecified. Thus, pathway cases are particularly useful to test theoretical 
causal mechanisms. The selected cases have been identified through semi-structured exploratory expert interviews. Drawing causal inference about the presence of causal mechanisms within single cases (Beach and Pedersen 2013), process-tracing is particularly useful for the analysis of cases for which researchers have an "initial suspicion" that the causal mechanism has been at work (Schimmelfennig 2015: 104).

Manifest control exists if the EUCO takes a decision on the substance of a legislative proposal that is later formally adopted by the Council of the EU. The decisions of the EUCO are indicated in its conclusions. The Council is latently controlled by the EUCO if it makes strategically a decision on a legislative proposal shortly before a EUCO summit to avoid that a decision is made by the EUCO. The Council, therefore, anticipates manifest control by the EUCO.

\subsection{The Patent Package}

Before the adoption of the patent package (PP), patent protection in the EU could be obtained by national patent offices of the member states or through the European Patent Office (EPO). After a patent was granted by the EPO, patent-holders needed to validate the patent in each member state where patent protection was sought. Due to the high costs of patent protection in the Union, it was decided to establish a uniform system of patent protection in the EU through the PP. The PP consists of two elements: a European patent with unitary effect and a Unified Patent Court (UPC). ${ }^{3}$ Yet, since unanimity among all EU countries could not be reached, 25 member states agreed to authorize enhanced cooperation for the creation of a European patent with unitary effect in March 2011 (Kroll and Leuffen 2015). To implement the authorization of enhanced cooperation, the Commission submitted two legislative proposals in April $2011(\mathrm{COM}(2011) 215$ final and $\operatorname{COM}(2011) 216$ final) alongside the international agreement on the UPC. These proposals required unanimity in the Council.

Despite discussions in May 2011, the Council was unable to reach unanimous agreement on the PP. Two issues proved to be particularly controversial during the negotiations: first, the location of the Court of First Instance of the UPC, with Germany, France and the United Kingdom (UK) being eager to host it; and second, the role of the Court of Justice of the EU (CoJ) to judge on patent law (Interview A). Although the PP "should never ever have ended up at the European 
Council", the matter was transferred to it, since "it was simply totally blocked at the Council" (Interview B). The role of the EUCO as a last resort to solve conflict within the Council is also indicated by a former participant in the negotiations according to whom the Council decided that "[n]ow, it's time that we use [the] atomic bomb [the EUCO] or that we completely drop it" (Interview A). Likewise, another interviewee commented that if the EUCO had not agreed on the PP, "this would have been the end of all" (Interview C, author's translation). After "very informal" (Interview B) discussions, the EUCO decided that the central division of the UPC would be located in Paris and two further specialized sections would be established in London and Munich (European Council 2012). Thus, in contrast to the Council, the EUCO was able to settle the conflict on the first issue. In line with hypothesis 1 , the PP was considered to be important by the HoSG due to its "high publicity" and the "disputed [use of] enhanced cooperation" (Interview A)-Italy and Spain had filed cases against the Council's decision before the CoJ. In addition, the "importance of the dossier for the Union was uncontroversial" because the comparatively high costs of patent protection diminished the EU's competitiveness (Interview C, author's translation). As commented by another EU official, "the conflict was relevant, because it was about money" (Interview D).

Given the PP's high importance, the Council's sectoral preferences prevented it from reaching a solution. As described by one EU official, the PP was "so political and [touched] so much the particular interests of member states that ministers did not feel that they had enough margin for manoeuvre in the negotiations. [...] [W] hen a minister is negotiating $[\ldots]$, he owns his own ministry only, while the Prime Minister owns all the ministries. And the Prime Minister has a global overview and can say 'Okay, this ministry loses this time, because it is more important for the country in general [...]. The biggest advantage of the European Council is that $[\ldots]$ they [the HoSG] know what they are supposed to fight for, but they also know what they can give up. Because they are the bosses of all the ministries and of all the dossiers" (Interview B).

Likewise, another interviewee argued that the EUCO regarded the $\mathrm{PP}$ "in more political than substantive terms [...]. The ministers rather saw the quality of the product and did not want to lower one's sights, whereas the bosses took the political dimension, the importance of the whole matter into account and said 'Okay, then we do it somehow. [... 
Since if we do not do it, the matter gets stuck. Then we end up with nothing'" (Interview E, author's translation).

Regarding the second issue, the EUCO proposed to reduce the role of the $\mathrm{CoJ}$ in the new litigation system by deleting Articles 6 to 8 from the legislative proposals (European Council 2012). Although the Council had already reached a common position and even had found an informal compromise with the EP in the trilogues (Interviews C, E, F), the EUCO reopened the compromise and demanded the Council to change its position. Since the UK was heavily opposed towards the arbitration of the $\mathrm{CoJ}$ on patent law (Interviews A, G) and expected a higher likelihood of concessions in the EUCO (Interview E), it brought the issue to the EUCO (Interviews A, C, D, G). Furthermore, the British government came under strong pressure at the domestic level (Interviews A, C, H).

During the negotiations in the EUCO, the other HoSG agreed to the British demand. Since the UK, France and Germany had to be among the ratifying states for the international agreement on the UPC entering into force, the UK had de facto a veto (Interviews A, C). Furthermore, the UK was able to "block" the implementation of the PP as a participating member of enhanced cooperation if the other member states would not have conceded to its demand (Interview E, author's translation). Thus, the EUCO changed the informal compromise due to "one member state breaking a consensus that had been achieved at a lower level before[hand] for political reasons at the last moment and applying the emergency brake" (Interview C). Evaluating the EUCO's role more critically, another EU official said that "the European Council did not function as arbitrator in that instance, but was [...] exploited as a forum in which the bosses do some straight talking" (Interview E, author's translation).

While the agreement of the EUCO was hailed as a "crucial point" by the Cypriot Council Presidency (Cyprus Presidency of the Council of the European Union 2012), it was heavily criticized by the EP. Yet, since the HoSG drafted parts of the final text of the agreement at their meeting (Interviews F, G), the solution was considered as a "binding mandate" by the Council (Interview F, author's translation). And, in fact, the Council of the EU "took [the] solution over one-to-one" in its position (Interview E, author's translation). Yet, the precise formulation by the EUCO left the Council no room for manoeuvre in its negotiations 
with the EP (Interviews D, E, F). In the words of one EU official: "The solution was precisely formulated by the European Council. And that was taken over one-to-one. So, nobody at the level of the ministers or the level of the ambassadors contested that $[\ldots]$. The difficulty was to agree with the Parliament on that. Since it was pretty clear, that if the Parliament wants something, the Council is unable to move, since it was part of a deal at the level of the bosses [...]" (Interview E, author's translation).

MEP Berhard Rapkay, rapporteur of the EP's Committee on Legal Affairs, complained that the EUCO "has decided to delete Articles 6 to 8 , and, as we know, if the European Council says that [...] it is for the Council of Ministers the Word of God which it follows [...]" (European Parliament 2013, author's translation).

Despite Parliament's strong criticism, a compromise was found in informal discussions between the EP and the Council (Council of the European Union 2012). While Articles 6 to 8 were deleted from the regulations on the European patent, the provisions were inserted in the international agreement on the UPC. Thus, the Council "found a solution that ensures the legality of the whole construction, while obeying to our political masters' [the EUCO's] guidelines to take them out of the regulation[s]" (Interview A). Although the EP was neither substantively nor procedurally satisfied with the outcome (Interview F), it approved the regulations on the EU patent with amendments on 11 December 2012, fearing that a European patent would otherwise never be created (Interviews C, D, F). On 17 December 2012, the Council adopted the regulations by consensus.

\subsection{The Decisions of the Council of the EU on the Relocation of Persons in Need of International Protection Among EU Member States}

In response to the increased influx of refugees to the EU through the Mediterranean Sea, the Commission submitted a ten-point action plan of immediate actions to be taken in April 2015. The action plan that was approved at a joint meeting of the Foreign and Home Affairs Council on 20 April 2015 called, inter alia, on the member states to examine options to establish an emergency relocation mechanism that aims at distributing persons in need of international protection from so-called frontline countries to other EU member states according to a distribution key. 
Although the EUCO endorsed the general idea at its extraordinary meeting on 23 April 2015, it called for a distribution scheme "on a voluntary basis" (European Council 2015b). In its Communication paper on a European Agenda for Migration $(\operatorname{COM}(2015) 240$ final) of midMay 2015, the Commission repeated its intention to submit a proposal for a temporary scheme to relocate refugees between the member states on the basis of a distribution key that takes several criteria of the member states, e.g. the size of the population or a member state's total GDP, into account.

On 27 May 2015, the Commission submitted its proposal for a Council decision establishing provisional measures in the area of international protection to the benefit of Greece and Italy $(\mathrm{COM}(2015) 286$ final). The proposal suggested to relocate in total 40,000 refugees from Greece and Italy, with 26,000 and 14,000 persons respectively, to the other member states within 24 months after the adoption of the decision. In contrast to the PP, the proposal could be adopted by QMV by the Council after having consulted the EP.

Although the negotiations in the Council were ongoing, the issue was on the EUCO's agenda in June 2015. In addition to the strong media attention and the fierce conflict among the member states on whether the system should be mandatory or voluntary, it "suited some [HoSG] for their own purpose to make it a leader's decision, while not leaving it to the ministers" (Interviews I, J). Furthermore, the wide-ranging implications of the proposal made it an issue for the cross-sectoral preferences of the HoSG. As one member of the cabinet of EUCO President Tusk explained: "The refugees are not simply a matter of who pays. [They] are not simply a matter of public border [as they would be] for the Ministers of the Interior. It is a matter of solidarity inside the EU. It is a matter of geopolitical relevance. And [in] that sense bringing the leaders [in] helps to have this wider view" (Interview K).

At its summit, the EUCO agreed to establish the relocation scheme calling for the proposal's "rapid adoption" by the Council "by consensus by the end of July" 2015 (European Council 2015a). Although the EUCO discussed "crucial, substantive elements of the file" (Interview I), it left the details of how many refugees would be taken by each member state open for the negotiations within the Council. As one EU official stated: "In June we [the European Council] said [...] '40,000 people will be relocated', which means it is a fact. We will relocate them, but ministers will agree by consensus how" (Interview B). Thus, by taking a 
"decision on the principle" (Interview L), the principal in that case left the agent with discretion on how to enforce its instruction.

Although the Justice and Home Affairs ministers did not reach agreement at an informal meeting on 9 July 2015, Jean Asselborn, Minister for Immigration and Asylum of Luxembourg that held the Council Presidency, said that the deadline set by the EUCO would be met (Ministry of European and Foreign Affairs of the Grand Duchy of Luxembourg 2015). Indeed, consensus on the relocation scheme was found on 20 July 2015 (Council of the European Union 2015). After the resolution of the EP on 9 September 2015, the proposal was formally adopted by the Council of the EU on 14 September 2015.

Yet, since the flow of refugees to the EU since then had intensified, the Commission tabled a second proposal in September 2015 that stipulated to relocate additionally 120,000 persons from Greece, Italy and Hungary to other EU member states (COM (2015) 451 final). After a first discussion in the Council of the EU, the EP approved the proposal without amendments on 17 September 2015. Since Hungary did not consider itself as a frontline country (European Parliament 2015; Interview $\mathrm{M}$ ), the initial proposal according to which 54,000 migrants would be relocated from Hungary was amended. In the subsequent negotiations in the Council, it was decided that the 54,000 migrants would be relocated from Greece and Italy in addition to the already foreseen number to be distributed from these countries. In contrast to the first Commission proposal, the decision to relocate 120,000 refugees was adopted by QMV in the Council, with the Czech Republic, Hungary, Slovakia and Romania voting against and Finland abstaining during an extraordinary meeting on 22 September 2015. While the EUCO had made the general decision that a relocation scheme will be created on the first proposal, its involvement was anticipated on the second proposal.

The fact that the proposal was adopted by an extraordinary Council meeting one day before an informal dinner of the HoSG on migration was held hints towards the anticipation by the Council of the EU. Although EUCO President Donald Tusk hesitated to call an extraordinary EUCO meeting on migration for being "afraid that it may jeopardize the Council work" (Interview B), he aimed at a solution on the proposal before the meeting of the HoSG. As one diplomat pointed out: "It [the voting] was also somehow his [Tusk's] idea [that] the Council will finish this on the day before [the EUCO]. And then there is a kind 
of silence in the debate and we can [...] [define] how we should proceed from now on" (Interview M, author's translation).

During the negotiations, the Justice and Home Affairs Ministers were clearly aware that if they would not adopt the proposal, the issue would end up at the EUCO (Interviews I, M). This led to a quicker decision by the Council. One interviewee stated that the announcement of a EUCO on the next day "accelerate[d] things because the [Council] Presidency was planning for two or three more weeks of discussions on this mechanism" (Interview B). In the words of another interviewee: "[T] f fact that leaders are there and the buck stops there [...] is quite important. $[\ldots]$ [What $\mathrm{t}]$ hey have done $[\ldots]$ in the refugee crisis with the Interior Ministers is [signalling] 'If you do not take a decision, we will meet'. [...] This helps greatly, because its builds [up] pressure on the ministers to compromise and to decide. [...] Why is that? Because otherwise ministers know that they will lose responsibility" (Interview N).

While this indicates that the Council feared to lose responsibility, the member states in favour of the proposal also anticipated that a decision in the EUCO would be taken by consensus (Interviews B, F, I, J). As one EU official argued: the voting "was prepared by the Luxembourg Presidency and they played clearly on the fact that there is no need of unanimity in the Council. Thus, the text was completely ready for adoption on the day before [the EUCO] and could be immediately signed [...]. So, this was also a psychological game" (Interview F, author's translation). Since a decision by consensus by the EUCO would have prevented the opportunity to outvote the reluctant member states (Interview I), the outcome of the EUCO would have looked differently to the decision that was adopted by the Council. In the words of one interviewee: if "you bring it back to [the EUCO], it is consensus [...]. And basically, if you have a majority that whole majority is then held to ransom by one or two who [are not] able to do it [the adoption]. If you keep it at the level of the Council, you can sideline them" (Interview J).

Despite the legal possibility of the Council to adopt the proposal by QMV if a decision would have been made by the EUCO, it would have been "politically" impossible for the Council to change the EUCO's decision given the hierarchy between the two institutions (Interviews J, L, O). Similarly, although the EUCO could have "overturned" the Council decision "legally through adopting in its conclusions that the text of the 22 [September 2016] should be abandoned", it would have been impossible "politically" since the members of the two institutions "are from the 
same governments" (Interview M, author's translation). And, indeed, since the proposal was not changed by the EUCO, Slovakia and Hungary filed cases against the decision before the CoJ. According to them, the proposal should have been adopted by unanimity and is contrary to the EUCO's decision of June 2015. Hence, according to them the Council acted "contrary to its mandate" (European Union 2016a, b).

In addition, EUCO President Donald Tusk did not want to put the issue back on the EUCO's agenda. Besides preferring a discussion on the Union's overall approach towards the migration crisis (Interview $\mathrm{M})$, Tusk wanted to avoid the "more difficult discussion" at the EUCO given the need of consensus (Interview M, author's translation). In addition, the EUCO President wanted to prevent a repeat of the acrimonious debate within the EUCO that had happened on the first proposal. As one diplomat remembered: on the first proposal "the leaders [were] standing up, screaming at each other around the dinner table. And that was this debate, $[\ldots]$ when somebody said that 'He would never admit Muslims into his country' and stuff like that. [...] And, I think, that had led Donald Tusk to [come to] the conclusion that he does not want to have that issue debated soon again amongst the leaders. [...] When there is a big clash, there might be hesitation to bring the matter back [to the EUCO] until one is more secure that there is room for [a] more orderly and less protagonistic debate" (Interview O).

\section{Theoretical Argument}

The empirical analysis shows that the EUCO controls the Council of the EU in two different ways. While the EUCO controlled the Council manifestly by changing the latter's position in the first case, the anticipation of a EUCO meeting on the next day led the Council to adopt the Commission's proposal in the second case. This suggests that the principal does not necessarily need to control the agent actively to change the agent's behaviour.

Regarding the first hypothesis, both cases were important for the HoSG as principals. The relocation scheme was under a high public and media attention and had wide-ranging implications for the member states. The PP was a costly and public issue due to the controversial use of enhanced cooperation. Furthermore, and confirming the second hypothesis, both cases were conflictual within the agent. While the agent was unable to reach a decision on the PP, the agent was divided on how 
to distribute the refugees between the member states in the second case. The condition of conflict within the agent for the control of the principal implies that agency loss might also result from the inability of the agent to fulfil its delegated task. This type of agency loss has received scarce attention in the principal-agent literature that has primarily examined agency loss being caused by an agent pursuing different interests from the principals. Since one reason why the Council of the EU is less able to make decisions compared to the EUCO is its division into policy-specific formations, the institutional design of the agent seems to affect the likelihood of this type of agency loss.

Furthermore, the empirical analysis suggests that a different decision rule between a divided agent and a principal might affect which control mechanism the principal exerts. While the EUCO controlled the Council manifestly in the case of the PP and, thereby, enabled it to adopt the PP by unanimity, a majority of member states was willing to adopt the second relocation proposal by QMV to avoid a decision by consensus in the EUCO. Yet, interestingly, the anticipation of a decision by the principal did not move the agent closer into line with the preference of its principal in that case as suggested in the principal-agent literature. Instead, it strengthened cooperation among the winning QMV coalition within the Council that aimed at preventing the involvement of the EUCO. This suggests that the anticipation of manifest control might have a different effect on the negotiation dynamics within a divided collective agent if the decision rule between the agent and the principal differs.

\section{Conclusion}

Focusing on the relationship between the EUCO and the Council of the $\mathrm{EU}$, this chapter has analysed the manifest and latent control the EUCO exerts on the Council in EU decision-making. Although the delegation relationship between the EUCO and the Council of the EU is not formalized in an explicit contract and the hierarchy is implicitly based on the superior position of the HoSG vis-à-vis the line ministers at the domestic level, the EUCO stands above the Council in the EU's political hierarchy. Being the highest political authority of the Union empowers the EUCO to make decisions on legislative proposals and thereby going beyond its treaty mandate in practice. This suggests that research on policy-making should focus on who is able to influence decisions rather than on who formally adopts legislative acts (cf. also Calvert et al. 1989). 
Furthermore, the analysis shows that a principal might control an agent through two mechanisms. On the one hand, a principal might control an agent manifestly by revising its decisions. On the other hand, the principal might control the agent latently through ex ante anticipation of the principal's action by the agent. Latent control implies that the absence of overt control by a principal should not be equated with no control. The analysis suggests that one reason why the principal might control the agent manifestly might be the failure of the agent to anticipate the principal's goals or the inability of a divided collective agent to reach a decision on its own beforehand. This implication can also be applied to other principal-agent relations in the EU. While the anticipation of member states' preferences by the Commission when initiating legislative proposals has been acknowledged (Crombez 1996), the Commission's failure to anticipate member states' preferences might explain the non-adoption or the withdrawal of legislative proposals.

Furthermore, the analysis shows that the range of available control instruments that a principal has at its disposal is not necessarily equal to the actual control a principal exerts. Although the EUCO has only few institutionally control instruments over the Council of the EU, its threat to interfere with the agent's actions is sometimes sufficient to prevent agency slack.

While the heterogeneity of preferences between member states within a collective principal has been increasingly taken into account in principal-agent studies of the EU (Dehousse 2008; Dür and Elsig 2011; Delreux 2008) and other international organizations (Nielson and Tierney 2003; Copelovitch 2010), individual member states are still primarily treated as unitary actors. Since the EUCO and the Council are both composed of members of the same governments, EU scholars predominantly assume that both institutions pursue the same preferences. Yet, the analysis shows that the EUCO and the Council may pursue diverging preferences in the political system of the EU. While the preferences of national ministers seem to be shaped also by departmental concerns, the HoSG seem to hold broader, cross-sectoral preferences. Thus, studies of principal-agent relations in the EU should distinguish more carefully between the two institutions.

Finally, the chapter shows that the EUCO's latent control was effective in changing the Council's behaviour in one case. Yet, this finding 
should be treated with caution. Since the chapter aimed at illustrating how latent control and manifest control work in the principal-agent relation between the EUCO and the Council, two cases were compared. To draw general conclusions on which control mechanism a principal chooses, a comparison of multiple cases or a large- $\mathrm{N}$ analysis is needed. Nevertheless, this chapter shows that the EUCO is not only an agenda setter or the key forum for policy coordination in the EU (Bickerton et al. 2015), but affects also legislative decision-making through its influence on the Council of the EU.

\section{Notes}

1. The terms "Council of the EU" and "Council" are used interchangeably.

2. 12 interviewees of the EU officials are working for the EP, 4 for the Commission, 17 in the Council of the EU and 4 in the cabinet of the European Council President Donald Tusk.

3. The UPC is a specialized patent court that has exclusive competences to handle disputes on patent matters between the participating member states. It was created through an international treaty outside the EU's legal framework.

\section{Cited Interviews}

\begin{tabular}{llll}
\hline A & Council Secretariat & February 2016 & Brussels \\
B & Council Secretariat & October 2015 & Brussels \\
C & Council Secretariat & February 2016 & Brussels \\
D & European Parliament & March 2016 & Brussels \\
E & Council Secretariat & March 2016 & Brussels \\
F & European Parliament & March 2016 & Brussels \\
G & Permanent Representation of member state & March 2016 & Brussels \\
H & Permanent Representation of member state & April 2016 & Brussels \\
I & Council Secretariat & April 2016 & Brussels \\
J & Council Secretariat & April 2016 & Brussels \\
K & Cabinet of the European Council President & October 2015 & Brussels \\
L & European Commission & March 2016 & Brussels \\
M & Permanent Representation of member state & March 2016 & Brussels \\
N & Council Secretariat & October 2015 & Brussels \\
O & Permanent Representation of member state & April 2016 & Brussels
\end{tabular}




\section{REFERENCES}

Abbott, K., Genschel, P., Snidal, D., \& Zangl, B. (2016). Two logics of indirect governance: Delegation and orchestration. British Journal of Political Science, $46(4), 719-729$.

Andeweg, R. (2000). Ministers as double agents? The delegation process between cabinet and ministers. European Journal of Political Research, 37(3), 377-395.

Beach, D., \& Pedersen, R. (2013). Process-tracing methods. Foundations and guidelines. Ann Arbor: The University of Michigan Press.

Bickerton, C., Hodson, D., \& Puetter, U. (Eds.). (2015). The new intergovernmentalism. States and supranational actors in the post-Maastricht era. Oxford: Oxford University Press.

Blom-Hansen, J. (2013). Legislative control of powers delegated to the executive: The case of the EU. Governance, 26(3), 425-448.

Bocquillon, P., \& Dobbels, M. (2013). An elephant on the 13th floor of the Berlaymont? European council and commission relations in legislative agenda setting. Journal of European Public Policy, 21(1), 20-38.

Bulmer, S. (1996). The European council and The council of the European Union: Shapers of a European confederation. Publius: The Journal of Federalism, 26(4), 17-42.

Calvert, R., McCubbins, M., \& Weingast, B. (1989). A theory of political control and agency discretion. American Journal of Political Science, 33(3), 588611.

Copelovitch, M. (2010). Master or Servant? Common agency and the political economy of IMF lending. International Studies Quarterly, 54(1), 49-77.

Council of the European Union. (2012). NOTE. From Presidency to Permanent Representatives Committee. Subject: Proposal for a regulation of the European Parliament and of the council implementing enhanced cooperation in the area of the creation of unitary patent protection, 16220/12.

Council of the European Union. (2015). Relocation of 40,000 refugees from Greece and Italy agreed by Council. Press Release 644/15.

Crombez, C. (1996). Legislative procedures in the European community. British Journal of Political Science, 26(2), 199-228.

Cyprus Presidency of the Council of the European Union. (2012). Press release - Unitary patent closer to the finishing line. Retrieved January 2016, from http://www.cy2012.eu/index.php/en/news-categories/areas/competitiveness/press-release-unitary-patent-closer-to-the-finishing-line.

De Schoutheete, P., \& Wallace, H. (2002). The European council. Notre Europe Research and European Issues. 19.

Dehousse, R. (2008). Delegation of powers in the European Union: The need for a multi-principals model. West European Politics, 31(4), 789-805. 
Delreux, T. (2008). The EU as a negotiator in multilateral chemicals negotiations: Multiple principals, different agents. Journal of European Public Policy, 15(7), 1069-1086.

Delreux, T., \& Adriaensen, J. (2017). Introduction. Use and limitations of the principal-agent model in studying the European Union. In T. Delreux \& J. Adriaensen (Eds.), The principal-agent model and the European Union (pp. 1-34). London: Palgrave MacMillan.

Dunleavy, P., \& Rhodes, R. (1990). Core executive studies in Britain. Public Administration, 68(1), 3-28.

Dür, A., \& Elsig, M. (2011). Principals, agents, and the European Union's foreign economic policies. Journal of European Public Policy, 18(3), 323-338.

Eggermont, F. (2012). The changing role of the European council in the institutional framework of the European Union. Consequences for the European integration process. Cambridge: Intersentia.

Epstein, D., \& O'Halloran, S. (1995). A theory of strategic oversight: Congress lobbyists, and the bureaucracy. Journal of Law Economics and Organization, $11(2), 227-255$.

Epstein, D., \& O'Halloran, S. (1999). Asymmetric information delegation, and the structure of policy-making. Journal of Theoretical Politics, 11(1), 37-56.

European Council. (2012). Cover note from the general secretariat of the council to delegations. Subject: European council. 28/29 June 2012. Conclusions. EUCO $76 / 12$.

European Council. (2015a). Cover note from general secretariat of the council to delegations. Subject: European council meeting (25 and 26 June 2015) Conclusions. EUCO 22/15.

European Council. (2015b). Special meeting of the European council, 23 April 2015 - Statement.

European Parliament. (2013). Debates. Tuesday, 11 December 2012 Strasbourg. Retrieved January 2016, from http://www.europarl.europa.eu/ sides $/$ getDoc.do?type $=$ CRE\&reference $=20121211 \&$ secondRef $=I T E M-$ 004 \&language $=\mathrm{EN} \&$ ring $=\mathrm{A} 7-2012-0001$.

European Parliament. (2015). MEPs give go-ahead to relocate an additional 120,000 asylum seekers in the EU. Press Release. Retrieved January 2016, from http://www.europarl.europa.eu/pdfs/news/expert/infopress/20150915IP R93259/20150915IPR93259_en.pdf.

European Union. (2016a). Action brought on 2 December 2015 - Slovak Republic $v$ Council of the European Union (Case C-643/15). Official Journal of the European Union C 38/41.

European Union. (2016b). Action brought on 3 December 2015 - Hungary v Council of the European Union (Case C-647/15). Official Journal of the European Union C 38/43. 
Franchino, F. (2000). Control of the commission's executive functions: Uncertainty conflict and decision rules. European Union Politics, 1(1), 63-92.

Gerring, J. (2007). Case study research principles and practices. Cambridge: Cambridge University Press.

Harstad, B. (2008). Do side payments help? Collective decisions and strategic delegation. Journal of the European Economic Association, 6(2-3), 468-477.

Hawkins, D., Lake, D., Nielson, D., \& Tierney, M. (2006). Delegation under anarchy: States, international organizations, and principal-agent theory. In D. Hawkins, D. Lake, D. Nielson, \& M. Tierney (Eds.), Delegation and agency in international organizations (pp. 3-38). Cambridge: Cambridge University Press.

Hayes-Renshaw, F., \& Wallace, H. (2006). The council of ministers. Basingstoke: Palgrave Macmillan.

Helms, L. (2005). Presidents, prime ministers and chancellors. Executive leadership in western democracies. Hampshire: Palgrave Macmillan.

Huber, J., \& Shipan, C. (2002). Deliberate discretion? The institutional foundations of bureaucratic autonomy. Cambridge: Cambridge University Press.

James, S., \& Copeland, P. (2014). Governing in the shadow of intergovernmental hierarchy: Delegation failure and executive empowerment in the European Union. Perspectives on European Politics and Society, 15(4), 518-533.

Johansson, K., \& Tallberg, J. (2010). Explaining chief executive empowerment: EU summitry and domestic institutional change. West European Politics, $33(2), 208-236$.

Kreppel, A. (2013). Legislative implications of the Lisbon treaty: The (potential) role of ideology. West European Politics, 36(6), 1178-1198.

Kroll, D., \& Leuffen, D. (2015). Enhanced cooperation in practice. An analysis of differentiated integration in EU secondary law. Journal of European Public Policy, 22(3), 353-373.

Leuffen, D., \& Hertz, R. (2010). If things can only get worse: Anticipation of enlargement in European Union legislative politics. European Journal of Political Research, 49(1), 53-74.

Lupia, A. (2003). Delegation and its Perils. In K. Strom, W. Müller, \& T. Bergman (Eds.), Delegation and accountability in parliamentary democracies (pp. 33-54). Oxford: Oxford University Press.

McCubbins, M., Noll, R., \& Barry, Weingast. (1987). Administrative procedures as instruments of political control. Journal of Law Economics and Organization, 3(2), 243-277.

McCubbins, M., \& Page, T. (1987). A theory of congressional delegation. In M. McCubbins \& T. Sullivan (Eds.), Congress. Structure and policy (pp. 409425). Cambridge: Cambridge University Press.

McCubbins, M., \& Schwartz, T. (1984). Congressional oversight overlooked: Police patrols versus fire alarms. American Journal of Political Science, 28(1), 165-179. 
Ministry of European and Foreign Affairs of the Grand Duchy of Luxembourg. (2015). Informal JHA Council - Ministers agree to the resettlement of 20,000 refugees in the EU, but delay their decision on the relocation of 40,000 asylum seekers until 20 July. Announces Jean Asselborn. Retrieved January 2016, from http://www.eu2015lu.eu/en/actualites/articles-actualite/2015/07/ info-jai-asselborn/.

Nielson, D., \& Tierney, M. (2003). Delegation to international organizations: Agency theory and world bank environmental reform. International Organization, 57(02), 241-276.

Ogul, M. (1976). Congress oversees the bureancracy. Pittsburgh: Pittsburgh University Press.

Ogul, M., \& Rockman, B. (1990). Overseeing oversight: New departures and old problems. Legislative Studies Quarterly, 15(1), 5-24.

Pollack, M. (2002). Learning from the Americanists (again): Theory and method in the study of delegation. West European Politics, 25(1), 200-219.

Puetter, U. (2014). The European council and the council. New intergovernmentalism and institutional change. Oxford: Oxford University Press.

Rasmussen, A. (2005). EU conciliation delegates: Responsible or runaway agents? West European Politics, 28(5), 1015-1034.

Rathbun, B. (2008). Interviewing and qualitative field methods: Pragmatism and practicalities. In J. Box-Steffensmeier, H. Brady, \& D. Collier (Eds.), The Oxford handbook of political methodology (pp. 685-701). Oxford: Oxford University Press.

Reykers, Y., \& Beach, D. (2017). Process-tracing as a tool to analyse discretion. In T. Delreux \& J. Adriaensen (Eds.), The principal-agent model and the European Union (pp. 255-281). London: Palgrave MacMillan.

Scharpf, F. (1999). Games real actors play. Actor-centred institutionalism in policy research. Oxford: Oxford University Press.

Schimmelfennig, F. (2015). Efficient process tracing. Analyzing the causal mechanisms of European integration. In A. Bennett \& J. Checkel (Eds.), Process tracing in the social sciences: From metaphor to analytical tool (pp. 98-125). Cambridge: Cambridge University Press.

Smeets, S. (2015). Unanimity and exposure in the EU council of ministers - or how the Dutch won and lost the ICTY debate. European Journal of Political Research, 54(2), 288-304.

Tallberg, J. (2008). Bargaining power in the European council. Journal of Common Market Studies, 46(3), 685-708.

van de Steeg, M. (2009). Public accountability in the European Union: Is the European Parliament able to hold the European council accountable? European Integration Online Papers, 13(3). Retrieved from http://eiop. or.at/eiop/pdf/2009-003.pdf. 
Vogiatzis, N. (2013). Exploring the European council's legal accountability: The court of justice and the European ombudsman. German Law Journal, 14(9), $1661-1686$.

Weingast, B., \& Moran, M. (1983). Bureaucratic discretion or Congressional control? Regulatory policymaking by the federal trade commission. Journal of Political Economy, 91(5), 765-800.

Werts, J. (2008). The European council. London: John Harper.

Wessels, W. (2015). The European council. London: Palgrave.

Wonka A. (2007). Die Europäische Kommission. Supranationale Bürokratie oder Agent der Mitgliedstaaten? Baden-Baden: Nomos Publisher.

\section{Author Biography}

Daniela Annette Kroll is a Research Assistant and $\mathrm{PhD}$ candidate at the Department of Politics and Public Administration and Associated Member of the Graduate School of Decision Sciences at the University of Konstanz. Her research is focused on intra- and inter-institutional decision-making in the EU and the process of differentiated integration. She examines the interactions between the European Council and the Council of the EU in EU decision-making in her $\mathrm{PhD}$ thesis. 